\title{
THE EFFECT OF WIND SPEED AT THE TOP OF THE TOWER ON THE PERFORMANCE AND ENERGY GENERATED FROM THERMOSYPHON SOLAR TURBINE
}

\author{
A. A. El-Haroun \\ Mechanical Power Eng. Dept., Faculty of Engineering, Menoufia University, Shebin \\ El-Kom, Egypt.
}

\begin{abstract}
Energy generated from wind turbine depends to a great extent on the wind speed at its inlet. The use of thermosyphon solar tower is an attempt to increase the air velocity at inlet of the wind turbine and of course to increase its power. The wind speed in a certain location changes always with time and with the height above ground surface. In this work, the effect of wind speed at the top of the tower on the performance as well as on the energy generated from thermosyphon solar turbine was studied theoretically. One location in Egypt was chosen for this study. The calculations were achieved mainly with the solar turbine located at tower bottom. For the purpose of comparison, the energy generated from the solar turbine was compared with that generated from free wind turbine at tower height with the absence of solar tower.
\end{abstract}

It was found that, the wind speed at the top of the tower results in a pressure drop which affects the performance of the thermosyphon solar turbine. This pressure drop increases with the rise in wind speed and will be zero only when the wind speed at the top of the tower reaches zero. It was also found that, there is an increase in friction losses through the tower and a decrease in both temperature difference between inlet and outlet of the tower and in heat losses from tower walls with the rise in wind speed. The inlet air velocity to the solar turbine and consequently its specific power were found to be increased with the increase in wind speed at the top of the tower. Therefore, the effect of wind speed at the top of the tower must be taken into account during thermosyphon solar tower calculations. By comparing the performance of solar turbine and the free wind turbine located at tower height with the absence of thermosyphon solar tower, it was found that the mean inlet air velocity to the solar turbine located at tower bottom and consequently its specific power are higher than those values for free wind turbine. The increase in mean inlet air velocity to the solar turbine is found to be $17 \%$ of its value for a free wind turbine. The increase in yearly specific energy generated from solar turbine is expected to be $57 \%$ of its value for free wind turbine.

Manuscript received from Dr. A.A. El- Haroun

Accepted on : $2 / 4 / 2001$

Engineering Research Journal Vol 24,No 3, 2001 Minufiya University, Faculty Of Engineering, Shebien El-Kom, Egypt, ISSN 1110-1180 


\section{KEYWORDS}

Renewable energy, Wind energy, Solar tower, Solar turbine, Thermosyphon, Solar energy.

\section{INTRODUCTION}

In the last decade intensive attention was paid to reduce the pollution of the air resulting mainly from the use of the conventional sources of energy in the thermal power plants. A way in this direction is the use of renewable energy sources $[1,2]$. The major disadvantage of renewable energy sources is their low specific power compared to the conventional sources of energy. In the field of wind energy, the specific power of a wind turbine can be improved by increasing the air velocity at the inlet of wind turbine $[3,4]$. Therefore the recent researches attempt to study how to increase the wind speed at the inlet of wind turbine by using different ways [5]. Some of them investigate the use of solar energy to increase the velocity of air flowing through tall tower connected with large collector $[6,7]$, or through only tall tower without collector, which named thermosyphon solar tower $[8,9]$.

in references $[8,9]$, the effect of different parameters on the performance of thermosyphon solar tower was studied theoretically. In the previous works the effect of wind speed at the top of the tower was not studied and there is a need to study this effect on the performance of thermosyphon solar tower and on the energy generated from solar turbine. This is the aim of the present study.

The mathematical model used in this study is explained in the next sections, followed by the results and conclusions of this work.

\section{LOCATION OF STUDY}

One location in south Egypt, named Kharga, where the solar radiation intensity is suitable, was chosen for this study. The wind speed frequency distribution for this location, at $10 \mathrm{~m}$ level above ground surface, is shown in Table 1 [10].

The solar wind turbine is located at the bottom of the tower. For the purpose of comparison, the energy generated from solar turbine is compared with that generated from free wind turbine at tower height with the absence of thermosyphon solar tower.

\section{MATHEMATICAL MODEL}

A rectangular cross section tower with $150 \mathrm{~m}$ length, $10 \mathrm{~m}$ width and $300 \mathrm{~m}$ height is chosen for this study [8]. The solar radiation intensity and the inlet temperature of air are assumed to be $600 \mathrm{~W} / \mathrm{m}^{2}$ and $293 \mathrm{k}^{\circ}$ respectively. The following parameters are considered in the present study, heat losses from the tower walls, the head losses through the tower due to friction, the variation in density and air velocity through the tower and the variation of the wind speed in location. Fig. 1 shows the solar tower and the location of the solar turbine and free wind turbine.

The flow problem under consideration can be represented by the following equations:

$$
h\left(\frac{\rho_{\text {arm }}}{\rho_{a w}}-1\right)-\frac{v_{2}^{2}-v_{I}^{2}}{2 g}-\frac{\left(\rho_{\text {locud }} h_{\text {turt }}: \rho_{\text {local }} h_{l \text { tric }}\right)}{\rho_{a w}}=0
$$


Where $h$ is the height of the tower, $\rho_{\text {atm }}$ is the average atmospheric density at inlet and exit of the tower, $\rho_{\mathrm{av}}$ is the average air density inside the tower, $g$ is the gravitational constant, $v_{1}$ is the vertical velocity of air at the inlet of the tower, $v_{2}$ is the vertical velocity of air at the outlet, $\rho_{\text {local }}$ is the local air density, $h_{\text {turb }}$ is the head corresponding to turbine power and $h_{\text {lfric }}$ is the head loss through the tower due to friction.

The head corresponding to turbine power $h_{\text {turb }}$ is calculated according to the relation

$$
h_{\text {turb }}=v_{l}^{2} \eta_{\text {total }} / 2 g c_{q}
$$

Where $c_{q}$ is the discharge coefficient through the turbine, assumed to be 0.6 , and $\eta_{\text {total }}$ is the total efficiency of converting kinetic energy of wind to electric energy, can be taken in practice as $0.405[11,12]$.

The frictional head losses through the tower $h_{1}$ fric are calculated from the following relation

$$
h_{l \text { sint }} \cdots f h v_{t}^{2} ; 2 g D_{H}
$$

Where $v_{t}$ is the average flow velocity through the tower, $D_{H}$ is the hydraulic diameter of the tower and $f$ is the friction factor. The friction factor in the above equation is determined from Prandtl and von Karman's equation as follows [13]

$$
\frac{1}{f}=4\left(2 \log \frac{D_{H}}{2 y}+1.74\right)^{2}
$$

Where $y$ is the height of roughness, assumed to be $0.09 \mathrm{~mm}$.

The hydraulic diameter can be calculated from the following relation

$$
D_{I I}=4 A_{c} U
$$

Where $A_{c}$ is the cross sectional area of the tower and $U$ is the circumference.

The atmospheric density at tower height $h$ is calculated using the following relation $[8,14]$

$$
\rho(h) \quad \rho_{\text {seatevel }}(1-0.000027 h)
$$

The horizontal wind speed at the top of the tower $v_{2 h}$, corresponding to its value at $10 \mathrm{~m}$ level above ground $v_{0}$, can be calculated using the Hellmann equation [11]

$$
v_{2 h}=v_{0}\left(\frac{h+h_{0}}{10}\right)^{a}
$$

Where $h_{0}$ is the tower bottom height above ground assumed to be $0.5 \mathrm{~m}$ and a is the height constant, depends on the smoothness and topography of location, and can be taken for this location as $0.2[4,11]$.

To study the effect of wind speed at the top of tower, the Newton's second law of motion is applied near the top of the tower and the following equation is obtained 


$$
\Delta P=\rho_{a v} v_{2 h}^{2}\left(v_{2 h}^{2}+2 v_{2}^{2}\right) / 2\left(v_{2 h}^{2}+v_{2}^{2}\right)
$$

The horizontal wind speed at the top of the tower results in a reduction in pressure $\Delta P$, which increases with the rise in its value and will be zero, when the horizontal wind speed reaches zero.

The exit pressure, without the effect of wind speed at the top of the tower, can be taken as the atmospheric pressure at the exit altitude according to the following relation $[8,14]$

$$
P(h)=P_{a}\left(1-0.003566 h / T_{i t}\right)^{5.26}
$$

Where $P(h)$ is the pressure at height $h, T_{a}$ and $P_{a}$ are the ambient temperature and pressure.

The exit pressure with the effect of wind speed at the top of the tower $P_{2}$ can be estimated as

$$
P_{2}=P_{a}\left(1-0.003566 h / T_{a}\right)^{5.26}-\Delta P
$$

The average density inside the tower $\rho_{\mathrm{av}}$ is calculated by averaging the inlet and exit densities $\left(\rho_{1}\right.$ and $\left.\rho_{2}\right)$, assuming the pressure at the inlet as atmospheric.

The exit temperature $T_{2}$ can be estimated using the following relation

$$
T_{2}=\left(Q_{\text {sol }}-Q_{\text {less }}\right) A_{t} /\left(\dot{m} C_{v}\right)+T_{1}
$$

Where $Q_{s o l}$ is the net solar radiation being received by the tower surface, $Q_{\text {loss }}$ is the heat lost by conduction and convection through the walls, $A_{i}$ is the surface area of the tower, $\dot{m}$ is the mass flow rate of air through the tower, $T_{1}$ is the inlet temperature to the tower and $C_{v}$ is the constant volume specific heat of air, assumed to be $0.718 \mathrm{kj} / \mathrm{kg} \mathrm{k}$. The surface area of the tower can be calculated as follows

$$
A_{t}-h U
$$

The heat losses through the wall $Q_{\text {loss }}$ is calculated from the following relation [15]

$$
Q_{\text {loss }}=\left(T_{i n s}-T_{\text {out }}\right) R_{\text {th }}
$$

Where $T_{\text {ins }}$ is the mean temperature inside the tower, $T_{\text {out }}$ is the temperature outside the tower and $R_{t h}$ is the overall thermal resistance.

$$
R_{t h}-\frac{1}{\alpha_{i n s}}: \frac{\Delta x}{k_{w}}: \frac{1}{\alpha_{\text {out }}}
$$

Where $\alpha_{\text {out }}$ is the heat transfer coefficient between the tower wall and outside air, assumed to be constant at $28.4 \mathrm{~W} / \mathrm{m}^{2} \mathrm{k}[8,16], \Delta x$ is the wall thickness taken as 0.32 $\mathrm{cm}, \boldsymbol{k}_{\mathrm{w}}$ is the thermal conductivity of the wall and is equal to $1.18 \mathrm{~W} / \mathrm{m} \mathrm{k}$ and $\alpha_{\text {ins }}$ is the heat transfer coefficient between the air inside the tower and the wall. $\alpha_{\text {ins }}$ is determined from the following relation [8];

$$
\alpha_{i n s} \quad N u k_{a i r} \quad D_{l i}
$$




$$
N u=0.023 \operatorname{Re}^{0.8} \operatorname{Pr}^{0.3}
$$

where $k_{\text {air }}$ is the thermal conductivity of air, assumed to be constant as $0.026 \mathrm{~W} / \mathrm{m} \mathrm{k}$ [16], $\mathrm{Nu}$ is the Nusselt number, Re is the Reynolds number and $P r$ is the Prandtl number, assumed constant at 0.7 [8].

The density of air at exit $\rho_{2}$ is determined from the ideal gas law as

$$
\rho_{2}=P_{2} / R_{a} T_{2}
$$

Where $R_{\mathrm{a}}$ is the gas constant for air.

The mass flow rate of air inside the tower is obtained from the continuity equation as

$$
\dot{m}=\rho_{1} A_{1} v_{1}=\rho_{2} A_{2} v_{2}
$$

Where $A_{1}$ and $A_{2}$ are the cross sectional area of the tower at inlet and outlet respectively, assuming to be equal.

The specific power of the turbine is estimated as

$$
s p=0.5 \rho_{\text {locul }} v^{3}{ }_{\text {local }} \eta_{\text {total }}
$$

Where $v_{\text {local }}$ is the local inlet air velocity to the turbine.

The yearly specific energy generated from the turbine can be estimated using the relation [17]

$$
E=I \cdot \int_{\tau_{t a d}}^{r_{\text {ruph }}} s p d t
$$

Where $F_{a}$ is the availability factor of wind turbine, taken as $0.95, \tau_{u n l}$ is the unworking time due to low wind speed and $\tau_{u n h}$ is the unworking time due to high wind speed. The wind turbine works only between start wind speed $v_{s}$ and stop wind speed $v_{s t}$, where $v_{s}=0.3 v_{r}, v_{s t}=2 v_{r}$ and $v_{r}$ is the rated wind speed. The rated wind speed depends on the mean wind speed in location. The optimum ratio between rated and mean wind speed can be estimated from [17]. The actual yearly working time for the turbine $\tau_{w}$ can be estimated according to the following relation.

$$
\tau_{u^{\prime}}=F_{a}\left(8760-\tau_{u m l}-\tau_{u m h}\right)
$$

The above equations (1-21) were solved simultaneously by iteration to calculate the heat losses from tower walls, the friction losses through the tower, temperature difference between inlet and outlet of the tower, inlet air velocity to the turbine and specific power. The yearly specific energy generated from the turbine, the yearly unworking time due to low and very high wind speed and the yearly working time were calculated for the solar turbine and for the free wind turbine and compared together. A computer program was written for this purpose.

\section{RESULTS AND DISCUSSION}

\section{Effect of Wind Speed at the top of the tower}

Figure 2 represents the relation between wind speed and the pressure drop at the top of the tower. The wind speed at the top of the tower $v_{2 h}$ results in a pressure drop, which increases with the rise in wind speed and will be zero when the wind speed reaches zero according to equation (8). Figure 3 shows the variation in inlet 
air velocity to the solar turbine and its specific power with the wind speed at the top of the tower. The increase in wind speed results in an enlargement in both inlet air velocity and specific power. Figure 4 clarifies the effect of wind speed on the friction losses through the tower. There is a rise in friction losses with the increase in wind speed. This is due to the rise in the air velocity inside the tower which has the main effect on the friction losses. Figures 5,6 represent the effect of wind speed on the temperature difference between inlet and outlet of the tower and the heat losses from tower wall $Q_{\text {loss. }}$. It is seen that, there is a decrease in both temperature difference and heat losses by the increase in wind speed. The heat losses from the tower wall depend mainly on the temperature difference inside and outside the tower. This clarifies the decrease in heat losses with the increase in wind speed.

\section{The Comparison between the Energy Generated from Solar Turbine and free Wind Turbine}

Figure 7 shows, for the two turbines, the variation of inlet air velocity to solar and free turbines with $10 \mathrm{~m}$ level wind speed in location. There is a growth in inlet air velocity with the increase in wind speed. Although the value of inlet air velocity to the free wind turbine $v_{2 h}$ seems to be sometimes greater than that for the solar turbine, the yearly mean inlet air velocity to solar turbine is found to be grosser, about $117 \%$ of the corresponding value for free wind turbine and $233 \%$ of the mean wind speed in location at $10 \mathrm{~m}$ level. The yearly specific energy generated from solar turbine in Kharga is found to be $157 \%$ of its value from the free wind turbine at tower height with the absence of thermosyphone solar tower.

The yearly mean inlet air velocity to the turbine $(\mathrm{m} / \mathrm{s})$, the yearly specific energy generated $\left(\mathrm{kW} \mathrm{hr} / \mathrm{m}^{2}\right)$, the yearly unworking time due to low wind speed $(\mathrm{hr})$, the yearly unworking time due to very high wind speed $(\mathrm{hr})$ and the yearly working time (hr) are represented on Table 2 for both solar turbine and free wind turbine in Kharga.

\section{CONCLUSIONS}

In the present work, the effect of wind speed at the top of the tower on the performance of thermosyphon solar turbine as well as on the energy generated was studied theoretically. One location in Egypt, where solar radiation intensity is expected to be high, was chosen for this study.

It was found that, the wind speed at the top of the tower results in a pressure drop which affects the performance of the thermosyphon solar turbine. This pressure drop increases with the rise in wind speed and will be zero only when the wind speed reaches zero. It was found also that, the increase in wind speed at the top of the tower results in an increase in friction losses through the tower, a decrease in temperature difference between inlet and outlet of the tower and a decrease in heat losses from tower walls. The inlet air velocity to the turbine and consequently specific power were found to be increased by the rise in wind speed. Therefore, the effect of wind speed at the top of the tower must be taken into account during thermosyphon solar tower calculations. By comparing the performance of the solar turbine and the free wind turbine which is located at tower height without the use of thermosyphon solar tower, it was found that the mean inlet air velocity to the solar turbine and the yearly specific energy generated are higher than the corresponding values for the free wind turbine. These values for the solar turbine were found to be $117 \%$ and $157 \%$ respectively of their values for the free wind turbine.

\section{REFERENCES}

[1] Kleemann, M.; Meliss, M.: Regenerative Energiequellen; Springer Verlag, 1988.

[2] Crome, H.: Windenergie - Praxis; Oekobuch Verlag; Freiburg, 1987.

[3] Hau,E.: Windkraftanlagen - Grundlagen. Technik, Einsatz, Wirtschaftlichkeit; Springer Verlag, Berlin, 1988. 
[4] Molly, J.P.: Windenergie - Theorie, Anwendung, Messung; Verlag C.F.Mueller, Karlsruhe, 1990.

[5] Aachen, G.: Windenergiekonzentratoren - Theoretische und experimentelle Studie zur Erhoehung der Leistungsdichte von Windturbinen in Wirbeln; BWK 35(1983)5.

[6] Haaf, W.; Friedrich, K.; Mayr, G.; Schlaich, J.: Solar Chimneys - Principle and Construction of the Pilot Plant in manzanares; Int.J.Solar Energy, pp. 3-20, Vol.2 (1983).

[7] Sabry,A.S.: Modeling and Simulation of Solar Chimney; Proceeding of Fifth Int.Conference of Fluid Mechanics, Cairo, 1995.

[8] Perez, S.; Tooker, B.; Bussi, T.: A Theoretical Study of a Thermosyphon Solar Turbine; Solar Energy, Vol.54, No.5, pp.345-350, 1995.

[9] El-Haroun, A.A.: A Theoretical Study of a Thermosyphon Solar Tower; Engineering Research Bulletin, Faculty of Eng., Menoufia University, Vol.21, No.2, pp. 91-104, 1998.

[10] Wind Data Obtained from the Egyptian Meteorological Authority, 1989.

[11] Twidell, J.: British Wind Energy Association - A Guide to small Wind Energy Conversion Systems; Cambridge University Press, 1987.

[12] Darwish, A.; Saygh, A.: Wind Energy Potential in Iraq; Jour.of Wind Engineering and Industrial Aerodynamics, pp 179-189, 27(1988)1.

[13] Khurmi, R.S.: Hydraulics, Fluid Mechanics and Hydraulic Machines; S.Chand Company, New Delhi, 1976.

[14] White, F.: Fluid Mechanics; McGraw-Hill Book Company, New York, 1994.

[15] Mikheyev, M.: Fundamentals of Heat Transfer; Mir Publishers, Moscow, 1968.

[16] Ozysik, M.: Basic Heat Transfer; McGraw-Hill Book Company, New York, 1977.

[17] El-Haroun, A.: Ein Beitrag tur Optimierung der Windenergienutzung-einige Beispiele ägyptischer und deutscher Standorte; Dissertation, TU-Dresden, 1993.

\section{NOMENCLATURE}

$A_{1} \quad$ cross-sectional area of the tower at inlet

$A_{2} \quad$ cross-sectional area of the tower at exit

$A_{l} \quad$ surface area of the tower

a height constant

$C_{v} \quad$ constant volume specific heat of air

$c_{q}$ discharge coefficient through the turbine

$D_{H} \quad$ hydraulic diameter of the tower

$d_{i} \quad$ tower depth

$f$ friction factor

$h$ height of the tower

$h_{\text {Ifrc }}$ head losses through the tower due to friction

$h_{0} \quad$ tower bottom height

$h_{\text {turb }}$ head corresponding to turbine power

$k_{a r} \quad$ thermal conductivity of air

$k_{w} \quad$ thermal conductivity of the wall

$L_{i} \quad$ tower length

$m$ mass flow rate of air through the tower

$\mathrm{Nu} \quad$ Nusselt number

$P \quad$ pressure

$P_{a} \quad$ ambient pressure

Pr Prandtl number

$Q_{\text {loss }}$ heat lost by conduction and convection through the wall

$Q_{s o l}$ net solar radiation being received by the tower surface

$R_{\tilde{a}} \quad$ gas constant of air

$R e \quad$ Reynolds number

$T_{1} \quad$ inlet temperature to the tower

$T_{2} \quad$ exit temperature

$T_{\text {ins }}$ mean temperature inside the tower

$T_{\text {o:t }}$ temperature outside the tower

$v_{0} \quad$ wind speed at $10 \mathrm{~m}$ level above ground 
$v_{1} \quad$ velocity of air at the inlet of the tower

$v_{2} \quad$ vertical velocity of air at the exit

$v_{2 n} \quad$ horizontal wind speed at the top of the tower

$v_{t} \quad$ average flow velocity through the tower

$\alpha_{\text {ins }}$ heat transfer coefficient between air inside the tower and the wall

$\alpha_{\text {out }}$ heat transfer coefficient between the tower wall and outside air

$\eta_{\text {total }}$ efficiency of converting kinetic energy of wind to electric energy

$\rho_{2} \quad$ density of air at the exit

$\rho_{\text {atm }}$ average atmospheric density at inlet and exit of the tower

$\rho_{a v} \quad$ average air density inside the tower

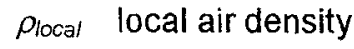

$\tau_{y} \quad$ yearly time 


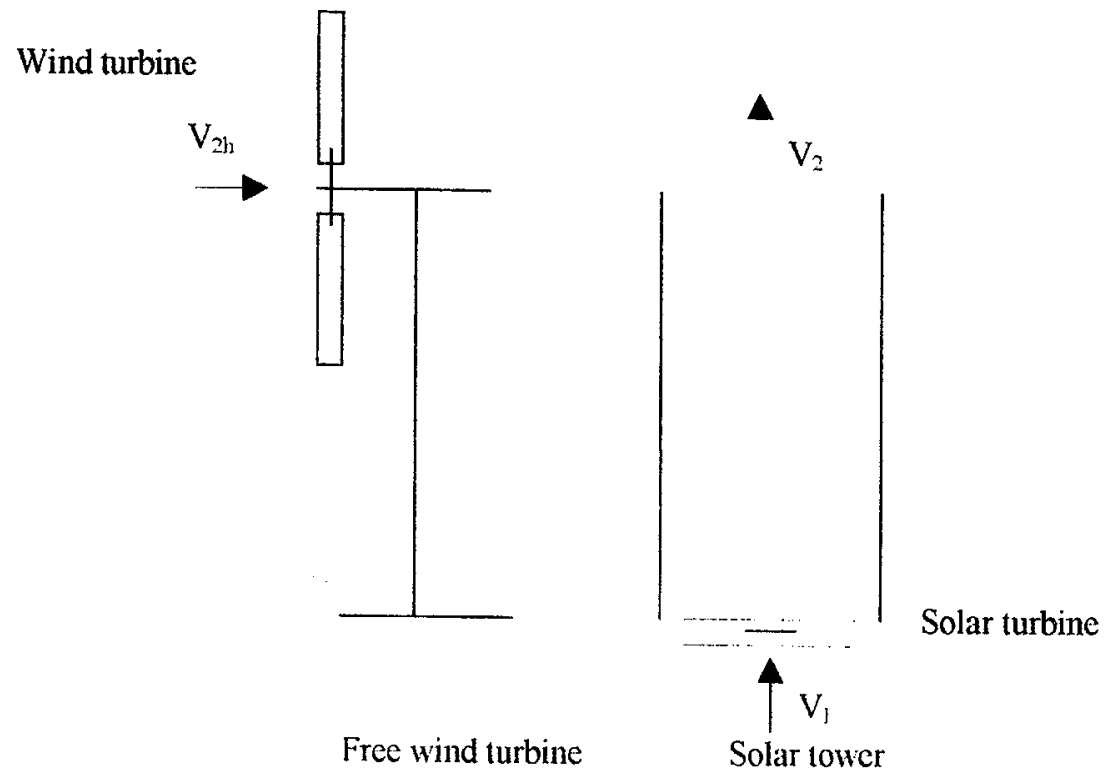

Fig. 1 The location of solar turbine and free wind turbine

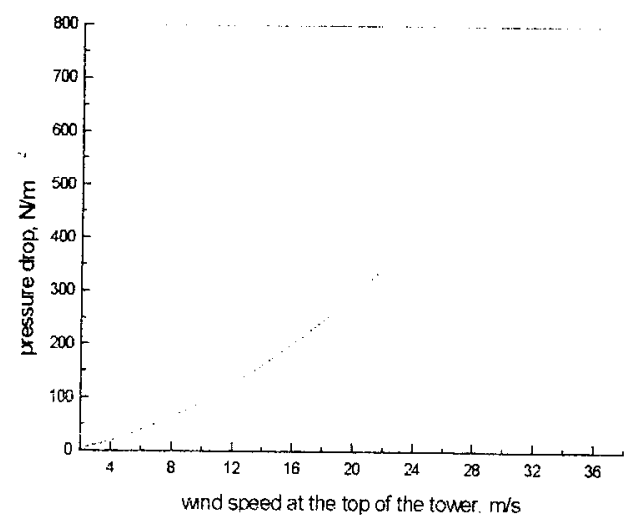

Fig. 2 Variation of pressure drop with wind speed at the top of the tower

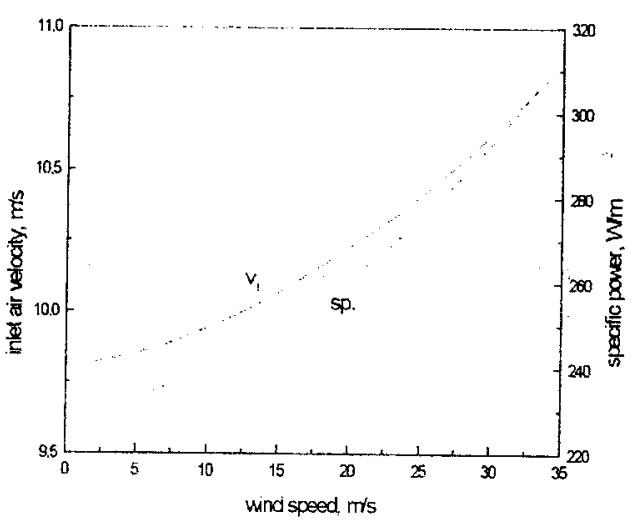

Fig. 3 Variation of inlet air velocity and specific power of solar turbine with wind speed at the top of the tower 


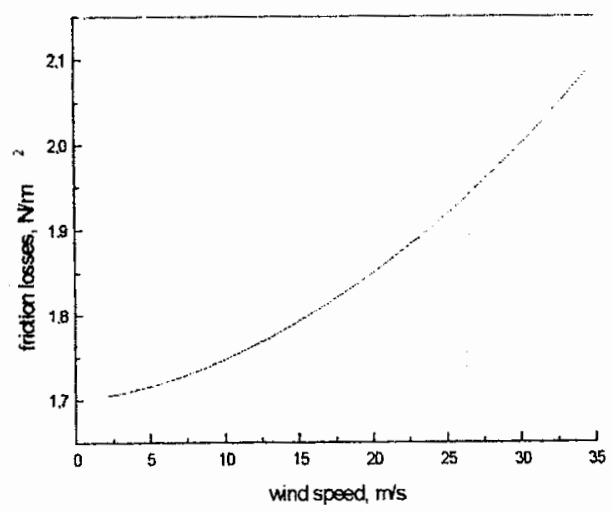

Fig. 4 Variation of friction losses through the tower with wind speed

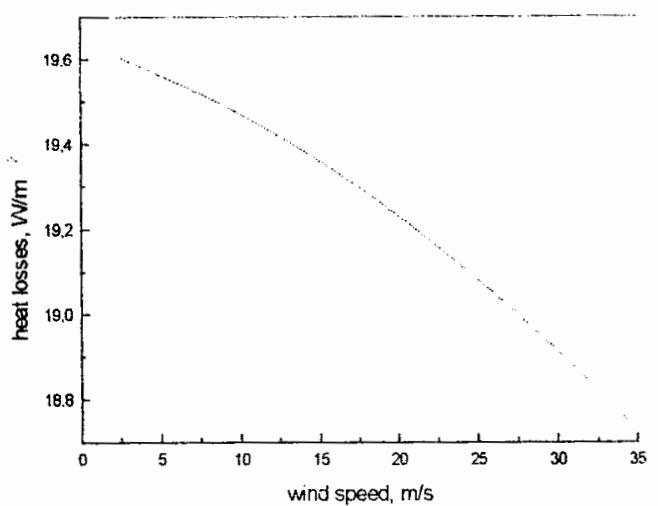

Fig. 6 Variation of heat losses from tower walls with wind speed

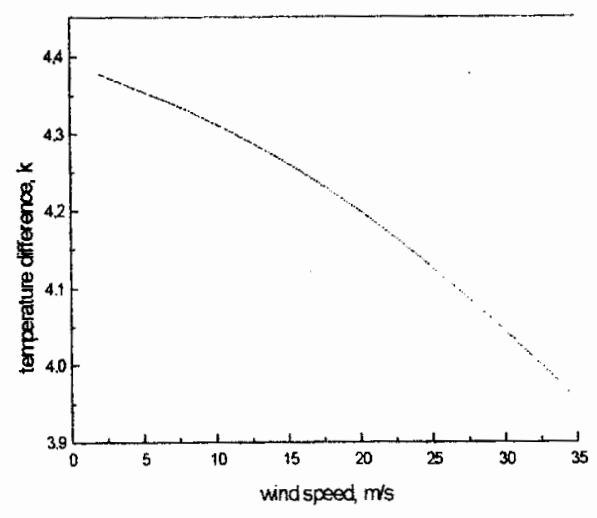

Fig. 5 Variation of temperature difference between inlet and outlet of the tower with wind speed

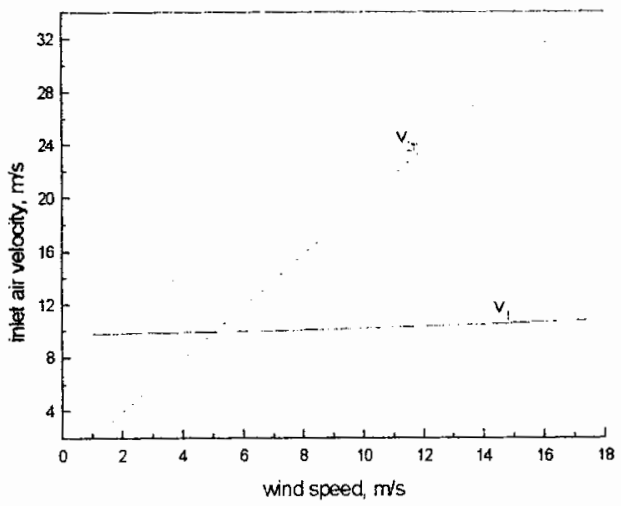

Fig. 7 Change of inlet air velocity to solar and free turbines with wind speed in location 
Table 1 wind speed frequency distribution for Kharga

\begin{tabular}{|c|c|c|c|c|c|c|c|c|}
\hline $\begin{array}{c}v_{0}, k \text { knot } \\
\mathrm{m} / \mathrm{s}\end{array}$ & $\begin{array}{c}1-3 \\
0.51-1.54 \\
\end{array}$ & $\begin{array}{c}4-6 \\
2.1-3.1 \\
\end{array}$ & $\begin{array}{c}7-10 \\
3.6-5.1\end{array}$ & $\begin{array}{r}11-16 \\
5.7-8.2 \\
\end{array}$ & $\begin{array}{c}17-21 \\
8.7-10.8 \\
\end{array}$ & $\begin{array}{c}22-27 \\
11.3-13.9 \\
\end{array}$ & $\begin{array}{c}28-33 \\
14.4-17 \\
\end{array}$ & $\begin{array}{c}>=34 \\
>=17.5\end{array}$ \\
\hline$\tau_{y}, \mathrm{hr}$ & 1748.4 & 1841.1 & 2349.1 & 2246.9 & 414.6 & 64.2 & 0.73 & 0 \\
\hline
\end{tabular}

Table 2 yearly mean inlet air velocity, sp. energy, unworking and working time for solar and free turbines

\begin{tabular}{|c|c|c|c|c|c|c|c|c|c|}
\hline \multicolumn{9}{|c|}{ solar turbine } & \multicolumn{5}{c|}{ free wind turbine } \\
\hline$v_{1 \mathrm{~m}}$ & energy & $\tau_{\text {un }}$ & $\tau_{\text {unh }}$ & $\tau_{\mathrm{w}}$ & $\mathrm{V}_{\text {2hm }}$ & energy & $\tau_{\text {unl }}$ & $\tau_{\text {unh }}$ & $\tau_{\mathrm{w}}$ \\
\hline 9.9 & 1530 & 0 & 0 & 8322 & 8.5 & 972 & 1748 & 575 & 6115 \\
\hline
\end{tabular}




\title{
تأثير سرعة الرياح عند قمة البرج على الآداءو والطاقة المتولدة من التربينة

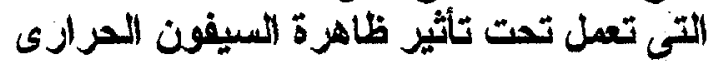

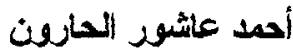 \\ مدرس بقسم هندسة القوى الميكانيكية، كلية الهندسة، جامعة المنوفية
}

\section{ملخص البحث}

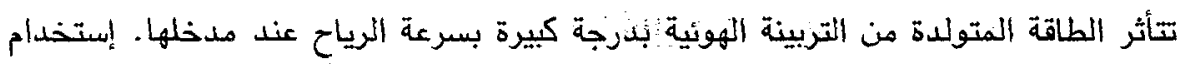

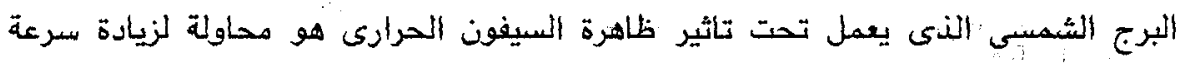

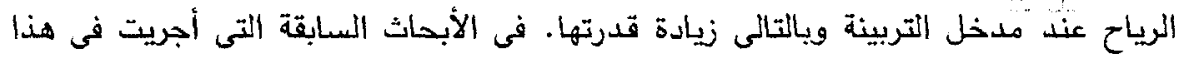

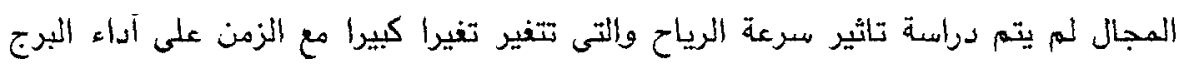

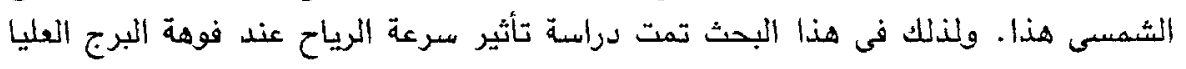

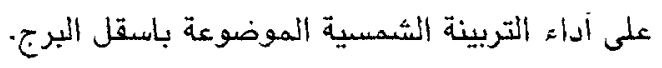

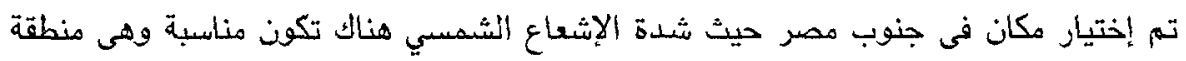

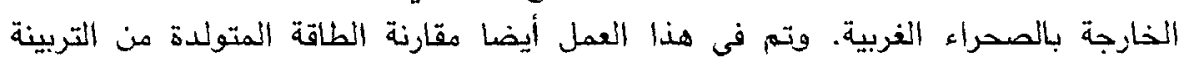

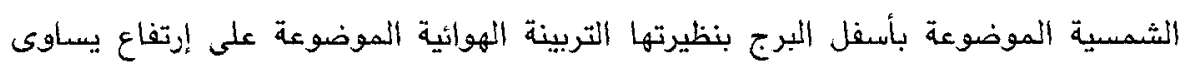

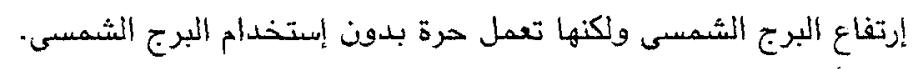

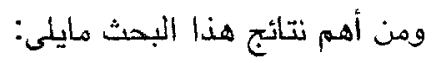

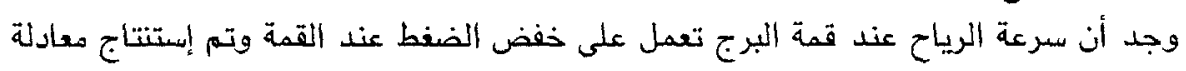

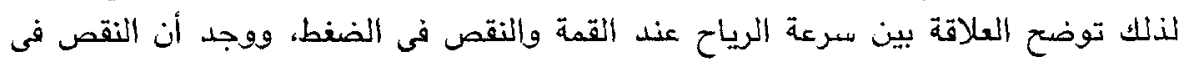

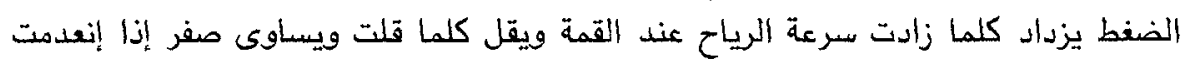

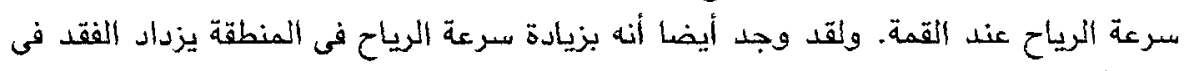

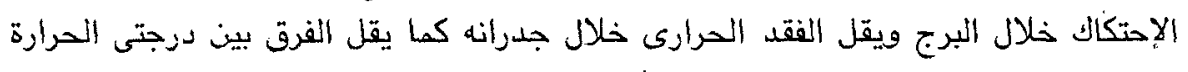

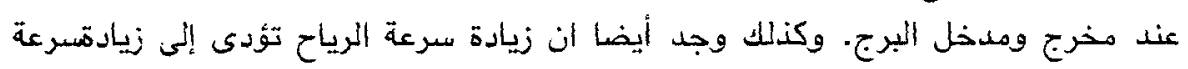

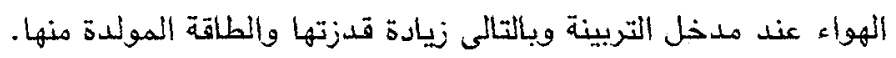

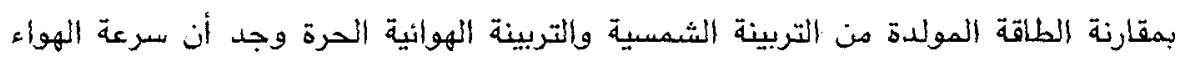

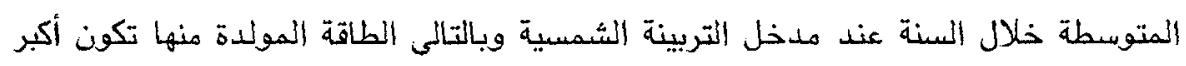

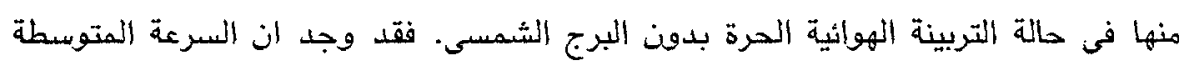

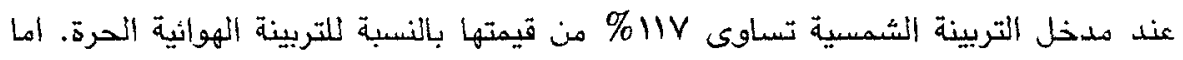

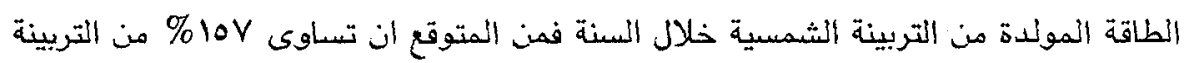

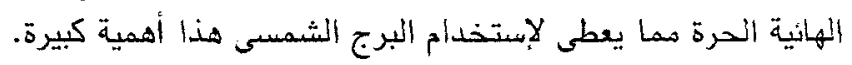

